\title{
Çanakkale Doğal Meralarında Bulunan Trifolium spumosum L. ve Trifolium angustifoilium L.'un Bazı Morfolojik, Biyolojik ve Tarımsal Özellikleri
}

\author{
Altıngül ÖZASLAN PARLAK ${ }^{1 \mathscr{9}}$ Ahmet GÖKKUŞ $^{1}$ \\ Ziya KARAKOYUNLU ${ }^{1}$ \\ Emine SÜRÜCÜ1 1 \\ ${ }^{1}$ Çanakkale Onsekiz Mart Üniversitesi Ziraat Fakültesi Tarla Bitkileri Bölümü, 17100/Çanakkale \\ $\triangle$ : ozaslan@comu.edu.tr
}

Geliş (Received): 02.11.2017

Kabul (Accepted): 15.12.2017

\begin{abstract}
ÖZET: Kurak ve yarı kurak meralarda tek yıllık baklagiller kendi kendini tohumlayabilmesi, kaliteli ot üretmesi, toprağa azot bağlaması, toprağın verimliliğini artırmasından dolayı ekosistem ve otlayan hayvanlar için çok önemli bitkilerdir. Bu türler sıcak ve kurak mevsimi tohumlarıyla geçirdikleri için, küresel ssınmaya bağlı artan kuraklık nedeniyle son yıllarda önemleri daha da artmaktadır. Bu yüzden bu çalışma Çanakkale meralarının yaygın yıllık üçgül türlerinden olan Trifolium spumosum L. ve Trifolium angustifolium L. türlerinin morfolojik, biyolojik ve tarımsal özelliklerini belirlemek amacıyla yürütülmüştür. Doğal meralarda 2011 yılında her bir türden 50 adet bitki örneği çiçeklenme döneminde toprak seviyesinden kesilerek toplanmış ve üzerinde biyometrik ölçümler yapılmıştır. T. spumosum ve T. angustifolium türlerinin ortalama bitki boyu sirasiyla 33.44 ve $45.06 \mathrm{~cm}$, ana dal say1S1 3.58 ve 5.34 adet, yan dal sayısı 2.17 ve 2.99 adet, ana dal çapı 2.56 ve $2.33 \mathrm{~mm}$, ana dalda yaprak sayısı 11.59 ve 18.84 adet, ana dalda kömeç sayısı 2.26 ve 2.53 adet, kömeçte çiçek sayısı 21.72 ve 55.98 adet, yaprak uzunluğu 5.36 ve $5.70 \mathrm{~cm}$, yaprakçık boyu 2.31 ve $3.09 \mathrm{~cm}$, yaprakçık eni 1.46 ve $0.42 \mathrm{~cm}$, sap oran $\% 65.65$ ve 51.09 , yaprak oranı $\% 21.48$ ve 17.63 , çiçek topluluğu oranı $\% 12.87$ ve 31.28 , bitki başına kuru madde verimi 5.73 ve 6.16 g, NDF oran1 \% 49.79 ve 53.02, ADF oran1 \% 45.80 ve 45.66, ADL oran1 \% 28.43 ve 31.04, ham protein oran1 da $\% 21.10$ ve 17.75, olarak belirlenmiştir. Yapılan korelasyon analizi sonucunda T. spumosum'un bitki boyu ile ana dal çapı, ana dal sayısı ile yan dal sayısı, sap oranı ile yaprak oranı ve çiçek topluluğu arasında önemli ilişki belirlenmiştir. T. angustifolium'da ise incelenen özelliklerin hemen hemen hepsi arasında önemli ilişki saptanmıştır. Her iki bitki de tarımsal açıdan oldukça önemli olup, tür içinde varyasyon oldukça yüksektir. Verim bakımından yüksek olan genotipler seçilerek Akdeniz kuşağı meralarının ıslahında kullanabilecek durumdadır. Bunun yanında bu bitkiler örtü bitkisi, arkadaş bitki ve koruyucu bitki olarak da kullanılabilecek özelliklere sahiptirler.
\end{abstract}

Anahtar Kelimeler: Trifolium spumosum L., Trifolium angustifolium L., morfolojik özellikler

\section{Morphological, Biological and Agricultural Characteristics of Trifolium spumosum L. and Trifolium angustifoilium L. Species Common Over the Rangelands of Çanakkale Province}

\begin{abstract}
Annual legumes are quite significant plants for ecosystem and grazing animals in arid and semi-arid regions since they can seed themselves, supply quality forage, fixate atmospheric nitrogen into soil and improve soil quality. These species have become even more significant in recent years together with increasing global warminginduced droughts since they spend hot and dry seasons with their seeds. This study carried out to determine morphological, biological and agricultural characteristics of annual trefoil species (Trifolium spumosum L. and Trifolium angustifolium L.) common over rangelands of Çanakkale province. From the natural rangelands, 50 plants of each species were cut from the soil surface at flowering period and biometric measurements were performed on these samples. For T. spumosum and T. angustifolium species, average plant heights were respectively measured as 33.44 and $45.06 \mathrm{~cm}$, number of main branches as 3.58 and 5.34, number of side branches as 2.17 and 2.99 , main branch diameters as 2.56 and $2.33 \mathrm{~mm}$, number of leaves on main branch as 11.59 and 18.84 , number of flower head on main branch as 2.26 and 2.53, number of lowers per flower head as 21.72 and 55.98, leaf lengths as 5.36 and 5.70 $\mathrm{cm}$, leaflet lengths as 2.31 and $3.09 \mathrm{~cm}$, leaflet widths as 1.46 and $0.42 \mathrm{~cm}$, shoot ratios as 65.65 and $51.09 \%$, leaf ratios as 21.48 and 17.63 , flower bunch ratios as 12.87 and $31.28 \%$, dry yield per plant as 5.73 and 6.16 g, NDF ratios as 49.79 and $53.02 \%$, ADF ratios as 45.80 and $45.66 \%$, ADL ratios as 28.43 and $31.04 \%$, crude protein ratios as 21.10 and $17.75 \%$. Significant correlations wee observed between plant height and main branch diameter, between number of main branches and number of side branches, between shoot ratio and leaf ratio and flower bunch of T. spumosum. For T. angustifolium species, significant correlations were observed among almost all traits. Both species are quite significant for agricultural purposes, but there were significant variations within each species. High-yield genotypes should be selected among them and selected genotypes should be used over Mediterranean rangelands. These species can also be used as cover crops, conservation or fellow plants.

Keywords: Trifolium spumosum L., Trifolium angustifolium L., morphological characteristics
\end{abstract}

\section{GİRIŞ}

Tek yıllık baklagiller Akdeniz ikliminin hüküm sürdüğü bölgelerin meralarında yayılış göstermektedir.
Tek yıllık baklagiller Akdeniz bölgelerinde çevre şartlarına dayanıklı ve çevreye en iyi adapte olmuş türlerdir (Fara ve ark., 1997). Bu türler kendi kendilerini 
tohumlayabilmesi, kaliteli ot üretmesi, havanın serbest azotunu toprağa bağlaması, toprağın verimliliğini artırması bu bitkilerin önemini artırmaktadır. Tek yıllık baklagillerden olan Trifolium angustifolium ile çalışan Driouech ve ark. (2008)'da iki yıllık çalışma sonucunda ortalama y1lda $139.2 \mathrm{~kg} \mathrm{ha}^{-1}$ azot fikse ettiklerini, $8.2 \mathrm{t}$ ha $^{-1}$ kuru madde ürettiklerini bildirmişlerdir. Bunun yanında örtü bitkisi, yeşil gübre ve yem bitkisi olarak kullanılmasından dolayı sosyal ve çevrenin sürdürülebilirliği açısından da oldukça önemlidir (Caporali ve ark., 2004). Tek yıllık baklagiller sıcak ve kurak mevsimi tohumlarıyla geçirdikleri için, küresel ısınmaya bağlı artan kuraklık nedeniyle son yıllarda önemleri daha da artmaktadır. Springborg (1986) Akdeniz bölgesi meralarında geleneksel otlatmanın önüne geçmenin oldukça zor olduğunu fakat küçük tohumlu mera baklagillerinin meralarda kullanılması ile yazın ağır otlatmanın zararlarını azaltabileceğini bildirmektedir.

Mera islah çalışmalarından tohumlama çalışmasında bölgede bulunan bitkilerin kullanılması, meranın iyileştirilmesinde başarıya götüren temel unsurlardan biridir. İthal olarak getirilen yem bitkileri tohumları, var olan mera bitkileri ile rekabete girmekte ve tohumlanan bitkiler rekabeti kaybederek yıllar geçtikçe vejetasyondan çekilmektedirler. Bu nedenle mera 1slah çalışmalarında doğal meralarda yem değeri ve kalitesi olan bitkiler belirlenerek üzerlerinde çalışılmalı ve ülke tarımına kazandırılmalıdır. Akdeniz ikliminin hüküm sürdüğü bölgemizde tek y1llık baklagiller oldukça önemlidir ve bu bitkilerin yem değerleri ortaya konulmamıştır. Bu çalışma ile tek y1llık baklagillerden olan Trifolium spumosum L. ile Trifolium angustifolium L. türlerinin morfolojik, biyolojik ve tarımsal özellikleri ortaya konulmuştur.

\section{MATERYAL ve YÖNTEM}

Çalışmada Çanakkale Onsekiz Mart Üniversitesi Terzioğlu yerleşkesindeki doğal alandan toplanan 2 adet yabani üçgül (Trifolium spumosum L. ve Trifolium angustifolium L.) bitkisi ele alınmıştır. Trifolium spumosum $L$. türü tek yıllık ve sürünücüden dike doğru gelişir, çiçek rengi kırmızımsıdan pembeye doğrudur. Trifolium angustifolium L. tek yıllıktır, bitki dik gelişir, çiçek rengi pembedir.

Bitki örnekleri tam çiçeklenmenin görüldüğü nisan ayında alınmıştır. Bunun için tesadüfü olarak belirlenen 50 bitkide kök boğazından hasat edilmiştir. Burada bitkilerin $\mathrm{cm}$ birimli cetvelle boy ölçümü yapıldıktan sonra kumpas ile ana dal çapları ölçülmüş, ana dal ve ana dalda yan dal sayıları belirlenmiştir. Salkımlardaki çiçek sayısı her bitkiden alınan 3 salkımdaki çiçekler sayılarak tespit edilmiştir. Yaprak uzunluğu her bitkiden şansa bağlı olarak 3 yaprakta yaprak sapının gövdeye bağlandığı yerden uç yaprakçığın ucuna kadar olan kısım cm cinsinden ölçülmüş ve ortalaması alınmıştır. Yaprakçık eni ve uzunluğu yaprak ölçümü yapılan örneklerden tesadüfü olarak seçilen 3 yaprakçı̆̆ın eni ve boyu $\mathrm{cm}$ cinsinden ölçülmüş ve ortalamaları alınarak belirlemiştir. Sap, yaprak ve kömeç oranları her bitkinin sap, yaprak ve kömeçleri ayrılarak $70^{\circ} \mathrm{C}$ sıcaklığında 48 saat firında kurutulmuştur. Kurutmadan sonra hassas terazide tartılarak sap, yaprak ve kömeç ağırlıkları belirlenip tüm bitkiye oranlanarak belirlenmiştir. Kuru madde verimi sap, yaprak ve kömeçlerinin kuru ağırlıkları toplanarak bitki başına kuru madde verimi hesaplanmıştır.

Çalışma sonucunda elde edilen morfolojik verirlerin değerlendirilmesi amaciyla istatistik analizinde MINITAP (Windows 13.0) programı kullanılmıştır. Türlerin kendi aralarındaki morfolojik özellikleri arasındaki ilişkileri belirlemek için korelasyon analizi yapılmış, biplot analizi yapılarak grafikleri çizilmiştir.

\section{BULGULAR ve TARTIŞMA \\ Trifolium spumosum $L$.}

Trifolium spumosum L. ortalama $33.44 \mathrm{~cm}$ (23.00$48.00 \mathrm{~cm}$ ) boylanmaktadır. Bitkide 3.58 adet ana dal ve her bir ana dalda 2.17 adet yan dal sayılırken, ana dal ortalama $2.56 \mathrm{~mm} \quad(2.15-3.32 \mathrm{~mm})$ kalınlığında ölçülmüştür. Ana dalda ortalama 11.59 adet, $5.36 \mathrm{~cm}$ uzunluğunda yaprak tespit edilmiştir. Yaprakta ortalama $1.46 \mathrm{~mm}$ eninde ve $5.36 \mathrm{~mm}$ uzunluğunda yaprakçıklar yer almıştır. Bitkide ortalama ana dalda 2.26 adet kömeç ve bir kömeçte 21.72 adet çiçek tespit edilmiştir. Bitki başına 0.20 ile $14.20 \mathrm{~g}$ arasında değişen kuru madde verimi ortalama $5.73 \mathrm{gr}$ olmuş ve oldukça geniş bir varyasyon göstermiştir. Bitkide kuru maddenin ortalama $\% 12.87$ 'si çiçek topluluğundan, \%65.65'i saplardan ve geri kalanı \%21.48'i yapraklardan meydana gelmiştir.

Üçgül ortalama $45.06 \mathrm{~cm} \quad(30.00-69.04 \mathrm{~cm})$ boylanmıştır. Bitkide ortalama $2.33 \mathrm{~mm}(1.60-3.80 \mathrm{~mm})$ kalınlığında, 5.34 adet ana dal ve her bir ana dalda 2.99 adet yan dal sayılmıştır. Ana dalda ortalama 18.84 adet, $5.70 \mathrm{~cm}$ uzunluğunda yaprak tespit edilmiştir. Yaprakta ortalama $0.42 \mathrm{~mm}$ eninde ve $3.09 \mathrm{~mm}$ uzunluğunda yaprakçıklar yer almıştır. Bitkide ortalama ana dalda 2.53 adet kömeç ve bir kömeçte 55.98 adet çiçek tespit edilmiştir. Bitki başına 1.3 ile $16.8 \mathrm{~g}$ arasında değişen kuru madde verimi ortalama $6.16 \mathrm{~g}$ olarak tespit edilmiştir. Bitkide kuru maddenin ortalama \%31.28'i çiçek topluluğundan, \% 51.09'u saplardan ve geri kalan $\% 17.63$ 'ü ise yapraklardan meydana gelmiştir. Kuru madde oran 1 ise ortalama \%43.78 (\%38.08-50.82) olarak belirlenmiştir.

Yem bitkilerinde kabaca kalite değerlendirilmesinde önemli k1staslardan biri olan NDF ortalama \%53.02 (\%50.17-54.99), ADF ortalama \%45.66 (\%42.1547.81), ADL ortalama \%31.04 olarak belirlenmiştir. Bitkide ortalama protein \%17.75 olarak kaydedilmiştir (Çizelge 2).

\section{Trifolium spumosum L. İncelenen Bazı Özellikler} Arasındaki İlişkiler

Trifolium spumosum L.'de bitki boyu ana dal çap1 arasında \%1 önemli ve olumlu bir ilişki gözlenmiştir (Çizelge 3, Şekil 1). Ana dal sayısı ile ana dalda yan dal sayısı arasında önemli ve olumlu bir ilişki vardır $(\mathrm{P}<0.01)$. Ana dal çapı ile ana dalda yan dal sayısı arasında önemli ve pozitif bir ilişki vardır $(\mathrm{P}<0.05)$. Sap 
oranının artmasıyla çiçek topluluğu ve yaprak oranı azalmaktadır $(\mathrm{P}<0.01)$.

Çizelge 1. Trifolium spumosum L.'da incelenen özelliklere ait veriler

\begin{tabular}{|c|c|c|c|c|c|}
\hline İncelenen Özellik & En küçük & En büyük & Ort. \pm St Hata & $V K$ & $n$ \\
\hline Bitki Boyu (cm) & 23.00 & 48.00 & $33.44 \pm 5.53$ & 32.50 & 50 \\
\hline Ana Dal Sayısı & 2.00 & 7.00 & $3.58 \pm 1.16$ & 3.00 & 50 \\
\hline Ana Dalda Yan Dal Sayısı & 0.66 & 4.66 & $2.17 \pm 0.69$ & 2.00 & 50 \\
\hline Ana Dal Çapı (mm) & 2.15 & 3.32 & $2.56 \pm 0.34$ & 2.41 & 50 \\
\hline Ana Dalda Yaprak Sayısı & 2.00 & 16.00 & $11.59 \pm 3.02$ & 12.00 & 50 \\
\hline Ana Dalda Kömeç Sayısı & 1.33 & 3.66 & $2.26 \pm 0.57$ & 2.16 & 50 \\
\hline Kömeçte Çiçek Sayısı & 13.00 & 23.33 & $21.72 \pm 3.68$ & 23.00 & 50 \\
\hline Yaprak Uzunluğu (cm) & 3.10 & 7.20 & $5.36 \pm 1.14$ & 5.47 & 50 \\
\hline Yaprakçık Uzunluğu & 1.90 & 3.30 & $2.31 \pm 0.31$ & 2.23 & 50 \\
\hline Yaprakçık Eni & 1.00 & 2.10 & $1.46 \pm 0.36$ & 1.30 & 50 \\
\hline Sap Oranı (\%) & 35.33 & 80.00 & $65.65 \pm 10.90$ & 69.61 & 50 \\
\hline Yaprak Oranı (\%) & 9.52 & 48.37 & $21.48 \pm 9.84$ & 20.51 & 50 \\
\hline Çiçek Topluluğu Oranı (\%) & 3.84 & 34.61 & $12.87 \pm 6.24$ & 11.74 & 50 \\
\hline Kuru Madde Verimi (g bitki ${ }^{-1}$ ) & 0.20 & 14.20 & $5.73 \pm 2.48$ & 5.49 & 50 \\
\hline Kuru Madde Oranı (\%) & 29.83 & 52.82 & $40.90 \pm 5.91$ & 41.85 & 50 \\
\hline NDF $(\%)$ & 47.65 & 51.80 & $49.79 \pm 1.01$ & 50.09 & 50 \\
\hline ADF (\%) & 44.13 & 48.35 & $45.80 \pm 0.88$ & 46.00 & 50 \\
\hline ADL $(\%)$ & 26.48 & 29.98 & $28.43 \pm 0.82$ & 28.43 & 50 \\
\hline Protein & 19.64 & 24.02 & $21.10 \pm 0.70$ & 21.08 & 50 \\
\hline
\end{tabular}

VK: Varyasyon katsayısı, n: Örnek sayısı, Ort: Ortalama, St Hata: Standart hata

Çizelge 2. Trifolium angustifolium $L$. incelenen özelliklere ait veriler

\begin{tabular}{|c|c|c|c|c|c|}
\hline Incelenen Özellik & En küçük & En büyük & Ort. \pm St Hata & $V K$ & $n$ \\
\hline Bitki Boyu(cm) & 30.00 & 69.00 & $45.06 \pm 9.28$ & 46 & 50 \\
\hline Ana Dal Sayısı & 3.00 & 12.00 & $5.34 \pm 2.23$ & 5 & 50 \\
\hline Ana Dalda Yan Dal Sayısı & 0.33 & 9.33 & $2.99 \pm 2.11$ & 2.83 & 50 \\
\hline Ana Dal Çapı(mm) & 1.60 & 3.80 & $2.33 \pm 0.39$ & 2.31 & 50 \\
\hline Ana Dalda Yaprak Sayısı & 2.00 & 63.00 & $18.84 \pm 10.86$ & 16 & 50 \\
\hline Ana Dalda Kömeç Sayısı & 1.00 & 7.00 & $2.53 \pm 1.57$ & 2.33 & 50 \\
\hline Kömeçte Çiçek Sayısı & 23.33 & 135.00 & $55.98 \pm 20.72$ & 53.29 & 50 \\
\hline Yaprak Uzunluğu (cm) & 4.08 & 8.72 & $5.70 \pm 1.13$ & 5.47 & 50 \\
\hline Yaprakçık Uzunluğu & 2.3 & 4.48 & $3.09 \pm 0.49$ & 2.99 & 50 \\
\hline Yaprakçık Eni & 0.24 & 0.66 & $0.42 \pm 0.08$ & 0.44 & 50 \\
\hline Sap Oranı (\%) & 30.77 & 70.21 & $51.09 \pm 8.82$ & 51.52 & 50 \\
\hline Yaprak Oranı (\%) & 7.41 & 33.08 & $17.63 \pm 5.75$ & 17.79 & 50 \\
\hline Çiçek Topluluğu Oranı (\%) & 16.05 & 49.77 & $31.28 \pm 7.27$ & 32.68 & 50 \\
\hline Kuru Madde Verimi(g bitki $\left.{ }^{-1}\right)$ & 1.3 & 16.8 & $6.16 \pm 4.33$ & 4.52 & 50 \\
\hline Kuru Madde Oranı (\%) & 38.08 & 50.82 & $43.78 \pm 3.14$ & 43.95 & 50 \\
\hline NDF (\%) & 50.17 & 54.99 & $53.02 \pm 1.24$ & 53.17 & 50 \\
\hline $\mathrm{ADF}(\%)$ & 42.15 & 47.81 & $45.66 \pm 1.24$ & 46.07 & 50 \\
\hline ADL (\%) & 29.13 & 34.19 & $31.04 \pm 1.35$ & 31.09 & 50 \\
\hline Protein & 15.96 & 21.04 & $17.75 \pm 1.13$ & 17.85 & 50 \\
\hline
\end{tabular}

VK: Varyasyon katsayısı. n: Örnek sayısı. Ort: Ortalama. St Hata: Standart hata

Kuru madde oranı ise ortalama \%40.90 (29.8352.82) olarak tespit edilmiştir. NDF (selüloz+hemiselüloz+lignin oranı) ortalama $\% 49.79$ (47.65-51.80) olarak kaydedilmiștir. ADF (selüloz+lignin oranı) ortalama \%45.80 (44.13-48.35) olarak tespit edilmiștir. ADL (lignin oranı) ortalama \%28.43 \pm 0.82 (26.48-29.98) olarak bulunmuştur. Bitkide protein ortalama \%21.10 olarak belirlenmiştir (Çizelge 1)
Trifolium angustifolium L. İncelenen Bazı Özellikler Arasındaki İlişsiler

Trifolium angustifolium L.'de bitki boyu ile sap oranı ve kuru madde verimi arasında \%1 seviyesinde önemli ve olumlu bir ilişki görülmüștür. Bitki boyu ile ana dal çap1 arasında $\% 5$ seviyede önemli seviyede pozitif ilişki gösterirken, çiçek topluluğu ile yaprak oranı arasında \%5'de önemli ve olumsuz ilişki belirlenmiştir (Çizelge 4, Şekil 2).vAna dal sayısı ile ana dalda yan dal sayısı, ana dal çapı, ana dalda yaprak 
sayısı, ana dalda kömeç sayısı ve kuru madde oranı arasında önemli seviyede olumlu yönde ilişki vardır $(\mathrm{P}<0.01)$. Ana dalda yan dal sayısı ile ana dal çapı, ana dalda yaprak sayısı, ana dalda kömeç sayısı ile kuru madde verimi arasında önemli ve olumlu bir ilişki vardır. Ana dal çapı ile ana dalda yaprak sayısı, ana dalda kömeç sayısı ve kuru madde verimi arasında önemli ve olumlu bir ilişki vardır $(\mathrm{P}<0.01)$. Ana dal çapın artması çiçek topluluğu oranında azalmaya neden olmuştur $(\mathrm{P}<0.05)$. Ana dalda yaprak sayısı ile ana dalda kömeç sayısı ve kuru madde verimi arasında önemli ve olumlu bir ilişki gözlenirken, yaprak oranı arasında \%5 seviyede önemli ve olumlu bir ilişki gözlenmiştir.

Ana dalda kömeç sayısı ile kuru madde verimi arasında olumlu ve önemli bir ilişki gözlenmiştir $(\mathrm{P}<0.01)$. Ana dalda kömeç sayısı ile sap oranı arasında önemli ve olumsuz bir ilişki gözlenmiştir $(\mathrm{P}<0.05)$. Sap oranı ile çiçek topluluğu ve yaprak oranı arasında önemli ve olumlu bir ilişki vardır $(\mathrm{P}<0.01)$.

Çizelge 3.Trifolium spumosum L.' de incelenen bitkisel özellikler arsındaki ilişkiler

\begin{tabular}{|c|c|c|c|c|c|c|c|c|c|}
\hline Özellik & BB & ADS & ADYD & ADÇ & ADYS & ADKS & SO & YO & ÇTO \\
\hline ADS & 0.086 & & & & & & & & \\
\hline ADYD & -0.217 & $0.360 * *$ & & & & & & & \\
\hline ADÇ & $0.650 * *$ & 0.134 & -0.105 & & & & & & \\
\hline ADYS & 0.058 & -0.053 & -0.140 & $0.339 *$ & & & & & \\
\hline ADKS & 0.198 & -0.073 & -0.199 & 0.210 & 0.202 & & & & \\
\hline SO & 0.206 & -0.068 & -0.145 & 0.169 & 0.105 & -0.125 & & & \\
\hline YO & 0.205 & 0.001 & 0.185 & -0.248 & -0.245 & 0.117 & $-0.824 * *$ & & \\
\hline ÇTO & -0.036 & 0.117 & -0.039 & 0.096 & 0.203 & 0.035 & $-0.448 * *$ & -0.138 & \\
\hline KMV & 0.108 & 0.102 & 0.183 & -0.079 & -0.163 & 0.111 & 0.090 & 0.160 & -0.236 \\
\hline
\end{tabular}

** \%1 seviyesinde; *\%5 seviyesinde önemlidir

BB: Bitki boyu. ADS: Ana dal sayısı. ADYD: Ana dalda yan dal sayısı. ADÇ: Ana dal çapı. ADYS: Ana dalda yaprak sayısı. ADKS: Ana dalda kömeç sayısı. SO: sap oranı. ÇTO: Çiçek topluluğu oranı. YO: yaprak oranı. KMV: Kuru madde verimi.

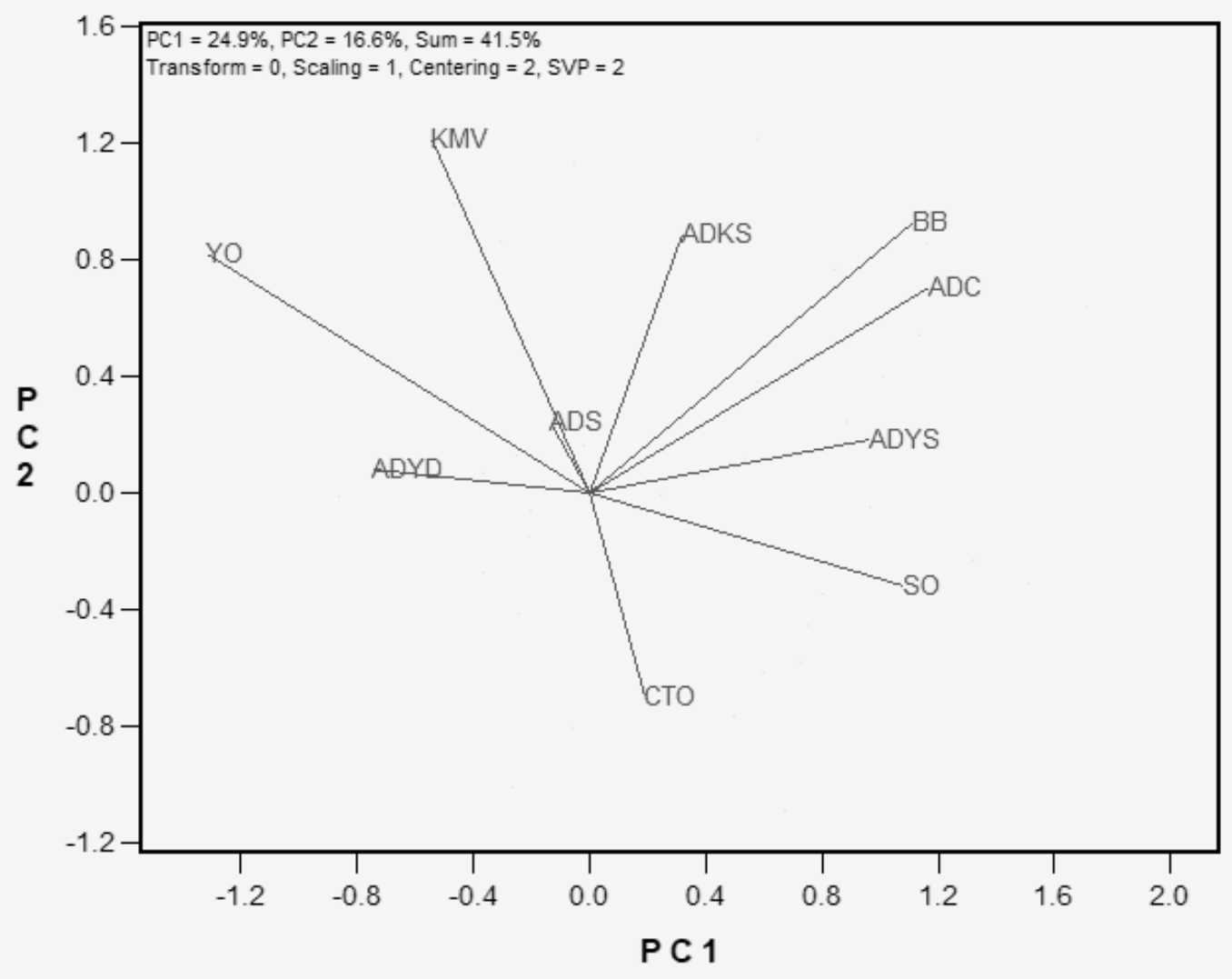

Şekil 1. Trifolium spumosum L biplot grafiği (Çizelge 3'te kullanılan kısaltmalar geçerlidir). 
Çizelge 4. Trifolium angustifolium $L$ 'de incelenen bitkisel özellikler arasındaki ilişkiler

\begin{tabular}{llllllllll}
\hline Özellik & BB & ADS & ADYD & ADC & ADYS & ADKS & SO & YO & CTO \\
\hline ADS & 0.269 & & & & & & & & \\
ADYD & 0.020 & $0.554^{* *}$ & & & & & & & \\
ADC & $0.317^{*}$ & $0.623^{* *}$ & $0.522^{* *}$ & & & & & & \\
ADYS & -0.019 & $0.568^{* *}$ & $0.762^{* *}$ & $0.551^{* *}$ & & & & & \\
ADKS & -0.044 & $0.533^{* *}$ & $0.833^{* *}$ & $0.486^{* *}$ & $0.738^{* *}$ & & & & \\
SO & $0.371^{* *}$ & 0.083 & -0.135 & 0.202 & -0.188 & $-0.317^{*}$ & & & \\
ÇTO & $-0.303^{*}$ & -0.238 & -0.026 & $-0.315^{*}$ & -0.043 & 0.268 & $-0.761^{* *}$ & & \\
YO & $-0.186^{*}$ & 0.172 & 0.240 & 0.088 & $0.343^{*}$ & 0.148 & $-0.572^{* *}$ & -0.097 & \\
KMV & $0.389^{* *}$ & $0.837^{* *}$ & $0.722^{* *}$ & $0.693^{* *}$ & $0.720^{* *}$ & $0.661^{* *}$ & 0.090 & 0.160 & -0.236 \\
\hline
\end{tabular}

** \% 1 seviyesinde; *\% 5 seviyesinde önemlidir.

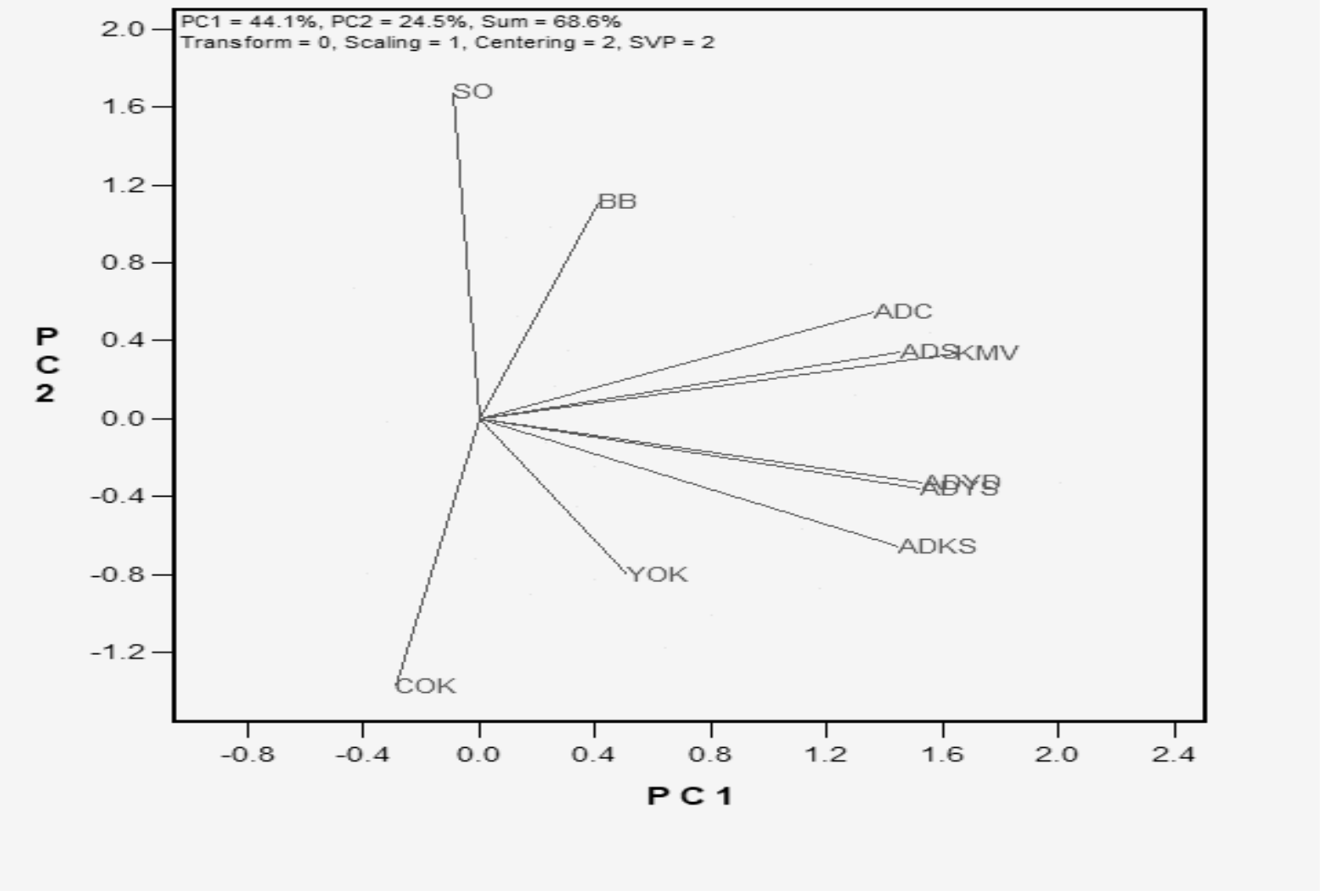

Şekil 2. Trifolium angustifolium biplot grafiği

Trifolium angustifolium'da bitki boyu ana dal sayısı, ana dalda yan dal sayısı, ana dal çapı ve ana dalda yaprak sayısı gibi gözle kolay ayırt edilebilen özellikler ile bitki başına kuru madde verimi arasında çok önemli ve olumlu korelasyon katsayısı belirlenmiş olması kuru madde verimi yüksek bitkilerin seçiminde seleksiyon kriteri olarak ele alınabilir. Bitkide kuru madde yönünden ortaya çıkan varyasyon ve bu varyasyona ait katsayının yüksek olması bitkide bu yönde yapılacak seleksiyon çalışmalarının başarılı olacağını göstermektedir. (Tükel ve Hatipoğlu, 1994; Koç ve Tan,1996; Street ve ark. 1998; Özaslan Parlak ve ark.,
2014). Aynı bitkide yaprak oranının oldukça az ve çiçek topluluğu oranının yüksek olduğu belirlenmiştir. İlk bakışta istenmeyen bir durum olarak görünebilir fakat çiçek topluluğunun fazla olması besin elementi miktarının artmasına neden olmaktadır. Çünkü çiçek toplulukları bitki yapraklarına eşit hatta daha fazla besin elementi içermektedir (Bakoğlu ve ark., 1999). Hem çiçek topluluklarının fazla olması tabii tohumlama için istenen bir durumdur. Bozulan bitki örtülerinin 1slahında doğal floradan toplanan bitki materyali daha başarılı sonuç vermektedir (Cocks, 1998). Bu konuda ICARDA 
tarafından yürütülen çalışmalardan oldukça başarılı sonuçlar alınmıştır.

\section{SONUÇ}

Trifolium spumosum $L$. ile Trifolium angustifolium $L$. türlerinde incelenen özellikler arasında geniş varyasyonlar tespit edilmiştir. Trifolium angustifolium'da kuru madde verimi ile bitki boyu, ana dal sayıs1, ana dalda yan dal sayısı, ana dal çap1, ana dalda yaprak sayısı, ana dalda kömeç sayısı arasında çok önemli bir ilişki belirlenmiştir. Aralarındaki bu ilişkileri dikkate alarak bu bitkiler seçilerek verimi yüksek bitkiler tarımımıza kazandırılmalıdır. Özellikle Akdeniz ikliminin hüküm sürdüğü meralarının iyileştirilmesinde başarıya ulaşmak için kaçınılmaz bitkilerdir. Bunun yanında bu bitkiler örtü bitkisi, arkadaş bitki ve koruyucu bitki olarak da kullanılabilecek özelliklere sahiptirler.

\section{KAYNAKLAR}

Bakoğlu A, Gökkuş A, Koç A 1999. Dominant mera bitkilerinin biomas ve kimyasal kompozisyonlarının büyüme dönemindeki değişimi. II. Kimyasal kompozisyondaki değişimler. Türk. Tar. ve Orm. Derg., 23(ek 2):495-508.

Bakoğlu A, Koç A, Erkovan Hİ, Özaslan A 1999. Erzurum yöresi mera vejatasyonlarında bulunan korunga (Onobrychis viciifolia Scops.)'nın baz1 özellikleri. III. Tarla Bitkileri Kongresi. 15-18 Kasim. Adana. 251-255.

Caporali F, Campiglia E, Mancinelli R, Paolini R 2004. Maize performances as influenced by winter cover crop green manuring. Italian Journal of Agronomy. 8 (1):37-45.

Cocks PS 1998. Ecological adaptation of pasture legumes and their response to management systems.
Centre for Legumes in Mediterranean Agriculture. Annual Report 1997-1998. p32-33.

Driouech N, Fayat A, Ghanem F, Al-Bitar L 2008. Agronomic performance of annual self-reseeding legumes and their self-establishment potential in the Apulia region of Italy. Proceedings of the 16th IFOAM Organic World Congress. Modena. Italy. pp. 1-4

Fara G, Franca A, Porqueddu C, Caredda S, Roggero PP 1997. Mediche e trifogli annuali autoriseminanti per usi foraggeri e non convenzionali. I. Adattamento e persistenza. Rivista di agronomia. 31: 1009-1018.

Hatipoğlu R, Tükel T 1994. Çukurova bölgesinde bulunan doğal domuz ayrığı (Dactylis glomerata L.) bitkisinin morfolojik. biyolojik ve tarımsal karakterleri üzerinde araştırmalar. Tarla Bitkileri Kongresi 25-29 Nisan 1994 İzmir. III Çayır-Mera ve Yembitkileri Bildirileri. 44-47.

Koç A, Tan M 1996. Erzurum meralarında doğal olarak yetişen melez yonca (Medicago varia L.)'nın bazı özellikleri. Türkiye 3.Çayır-Mera ve Yem Bitkileri Kongresi.17-19 Haziran 1996. Erzurum. 621-626.

Özaslan-Parlak A, Gökkuş A, Samıkıran E, Şenol MY 2014. Bazı yabani korunga türlerinin morfolojik ve agronomik özelliklerinin incelenmesi. ÇOMÜ Ziraat Fakültesi Dergisi 2(2): 111-117.

Springborg R 1986. Impediments to the transfer of Australian dryland agricultural technology to the Middle East. Agriculture. Ecosystems and Environments 17:229-251.

Street K, Cocks P, El Moneim AA 1998. Ecology of subterranean vetch (Vicia sativa subsp. Amphicarpa) in North Syria. Centre for Legumes in Mediterranean Agriculture. Annual Report 19971998. p33-34. 